\title{
航空機のゼロ点位置が与える横方向操縦性への影響 Effect of Zero Position on Lateral-Direction Controllability of Airplane
}

\section{砂生 健志（神奈川工大 [学部生]） 正 小林 修（神奈川工大） 正 水野 敏広（神奈川工大）}

Takeshi SASOH, Kanagawa Institute of Technology, Shimo-ogino 1030, Atsugi, Kanagawa

Osamu KOBAYASHI, Kanagawa Institute of Technology, Shimo-ogino 1030, Atsugi, Kanagawa

Toshihiro MIZUNO, Kanagawa Institute of Technology, Shimo-ogino 1030, Atsugi, Kanagawa

Key Words: Airplane, Pilot, Stability \& Control

\section{1. 序論}

航空機の横方向の経路コントロールはパイロットがバン ク角を制御しながら行われるため、バンク角の制御のし易 さが操縦性に大きく影響してくる。

ダッチロール、ロールおよびスパイラルの横方向運動モ 一ド特性が安定であっても、パイロットがバンク角を制御 しようとすると逆にバンク角の動きが振動的になることが ある（Pilot Induced Oscillation, P.I.O.）。この現象は人閒が 操縦しているときの機体特性であるので、パイロットを含 めた閉ループ伝達関数に着目した。パイロットがバンク角 制御した場合の閉ループの簡易モデルを Fig.1 に示す。

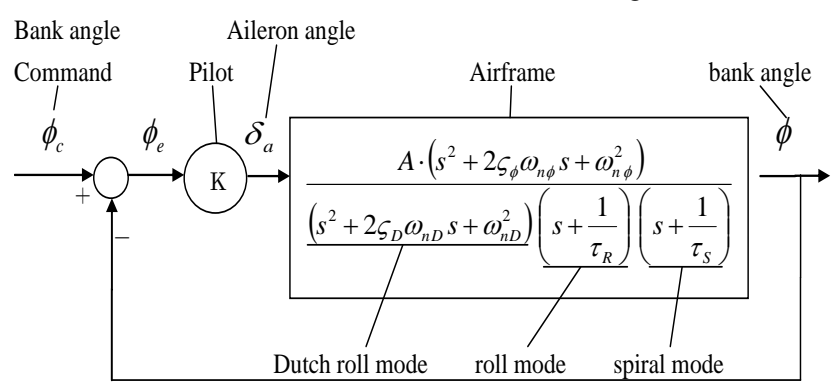

Fig.1 Closed loop model of bank control この閉ループの伝達関数は次式となる。

$\frac{\phi(s)}{\phi_{c}(s)}=\frac{K \cdot A\left(s^{2}+2 \varsigma_{\phi} \omega_{n \phi} s+\omega_{n \phi}^{2}\right)}{\left(s^{2}+2 \varsigma_{D} \omega_{n D} s+\omega_{n D}^{2}\right)\left(s+\frac{1}{\tau_{R}}\right)\left(s+\frac{1}{\tau_{s}}\right)+K \cdot A\left(s^{2}+2 \varsigma_{\phi} \omega_{n \phi} s+\omega_{n \phi}^{2}\right)}$ これは閉ループの安定性を示すその特性多項式が機体のみ の伝達関数の分子式、すなわちゼロ点の影響を受けること を表している。また、バンク角制御時の P.I.O.は振動モー ドであるダッチロールモード特性の変化によるものである ことが知られているので、本研究ではダッチロール根に対 する相対的なゼロ点の配置による操縦性への影響について 検討することとした。

すなわち本研究の目的は以下のとおりである。航空機の 横方向伝達関数のゼロ点のダッチロール根に対する相対位 置によって航空機の操縦性がどのように変化するのかをつ ライトシミュレータ実験検討し、操縦し易い領域およびし 難い領域を区分けする。さらにエルロン・ステップ入力時 の機体応答解析により、それらの領域区分と機体応答の形 との関係を見出す。

\section{2. 検討手順}

2-1 航空機モデル

本研究のモデル機体は P2V-7 改可変特性機で、代表的な 巡航時の諸データを使用した ${ }^{1)}$
質量 $=28600 \mathrm{Kgf} \quad$ 速度 $=89.55 \mathrm{~m} / \mathrm{s} \quad$ 飛行高度 $=10000 \mathrm{ft}$ 2-2 フライトシミュレータ装置

本学小林研のワイド な模擬視界を有するフ ライトシミュレータを 用いた(Fig.2-1)。これは 機体運動の変化を計算 するサーバ PC と模擬 視界を作成する 5 台の クライアント PC・プロ ジェクタ・スクリー ンから構成されている。 2-3 ゼロ点配置

P2V-7 モデル機のダッチロール根とゼロ点を複素平面 ( $\mathrm{s}$-平面)上にプロットし、それをもとに検討すべきゼロ点 として全部で 36 個を Fig.2-2 に示すように配置して、シミ ユレータに組み込みこむとともに、応答解析データとして 供した。

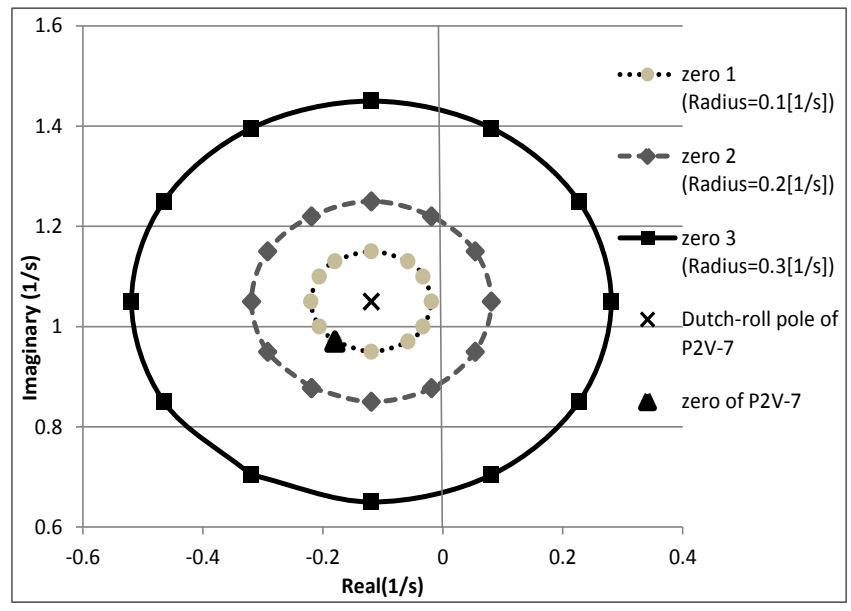

Fig.2-2 Location of candidate's zeros around Dutch-roll pole

2-4 シミュレータ実験手順

水平直線飛行状態からバンク角を $\pm 30^{\circ}$ 一変更し保持し続 け、その後水平飛行に戻すタスクを行い、その際の操縦の し易さを Cooper-Harper パイロット・レーティング・スケ ールを用いて評価する。Cooper-Harperのパイロット・レー ティング (P.R.) は 1 から 10 の段階からなっている ${ }^{2)}$

P.R. $10 \rightarrow$ タクが達成できない (uncontrollable)。

P.R. 7〜9 9何とかタスクを達成できるが、作業負担が大 き過ぎる(unacceptable)。

P.R. 4〜6 6作業負担がかかるが、タスクを達成できる (acceptable)。 
P.R. 1〜3 3 タスクを達成でき、作業負担も少ない (satisfactory)。

2-5 機体応答解析の手順

エルロン操舵に対する機体(airframe)のロール応答の伝 達関数を同伴系の状態方程式の形に変更して、36 個のゼロ 点それぞれについて運動解析を行う。それら応答計算結果 をシミュレータ実験結果と比較検討してパイロットレーテ イングとの関係を探る。さらに、P2V-7 モデル機の特性の うちエルロン操舵時に発生するヨーイングモーメントの量 を示寸有次元空力微係数 N $\delta$ a の值を変化させたときのゼロ 点位置の変化を調べ、シミュレータ実験結果と比較検討す る。

\section{3. シミュレータ実験結果}

ダッチロール根まわりのゼロ点配置図の上に実験結果で あるパイロットレーティング分布を Fig.3 に示す。ダッチ ロール根の極を中心にして取り巻く円状のゼロ点には内側 から外側に Z,Q,R の記号を、また極から放射状に反時計回 りに数字を付けている。

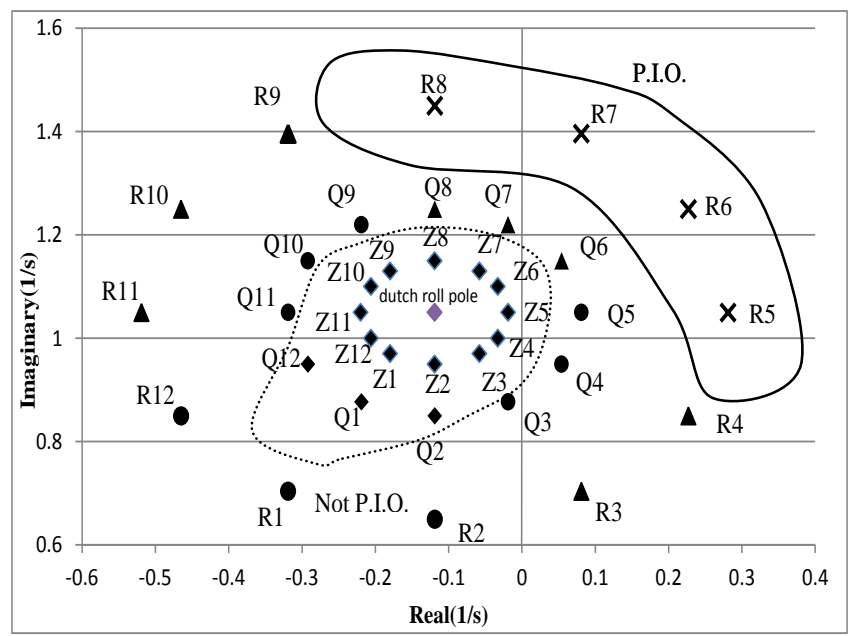

ค. P.R.=1 3 (satisfactory)

- ・ P.R. $=4 \sim 6$ (acceptable)

A • P.R. $=7 \sim 9$ (unacceptable)

$\times \cdot$ P.R.=10 (uncontrollable)

Fig.3 Result of flight simulator experiment

これらの結果のうち P.I.O.に入り易い区域と入り難い領 域があり、P.R.=10 を入り易い区域とし、実線の領域線、 P.R. $=1 \sim 3$ を入り難い区域とし、点線の領域線で表した。

\section{4. 機体応答解析の結果}

エルロン・ステップ入力に対するロールレート応答につ いての運動解析結果を Fig.4-1、Fig.4-2 に示す。これらの図 から次のことがいえる。

(1)当然のことながらダッチロール根（極）からの任意の 放射線上ではゼロ点が極から離れるに従って、ダッチロー ル振動の成分が大きくなっていく $(\mathrm{Z}<\mathrm{Q}<\mathrm{R}$ と振動が大きく なっている）。この振動成分の増大は操縦性の劣化に対応 している。

(2)極からのゼロ点の方向によって振動成分の初期位相 が変化するが、その影響により、極から左下にゼロ点があ る場合 $(\mathrm{Z} 1, \mathrm{Q} 1, \mathrm{R} 1)$ はステップ応答における最初のピーク が明快になる方向にダッチロール成分が現れている。

これに対してゼロ点が右上の場合 $(\mathrm{Z} 7, \mathrm{Q} 7, \mathrm{R} 7)$ は最初に ピークが現れようとすると続いて大きな応答になるように
振動成分が加わる形となる。後者の場合、そのままの操舵 を行えばオーバーコントロールになるであろうし、あるい は最大応答量が同じ位になるように操舵調整すれば、応答 が遅くなってしまう。いずれにしても P.I.O.を発生し易く なると考えられる。

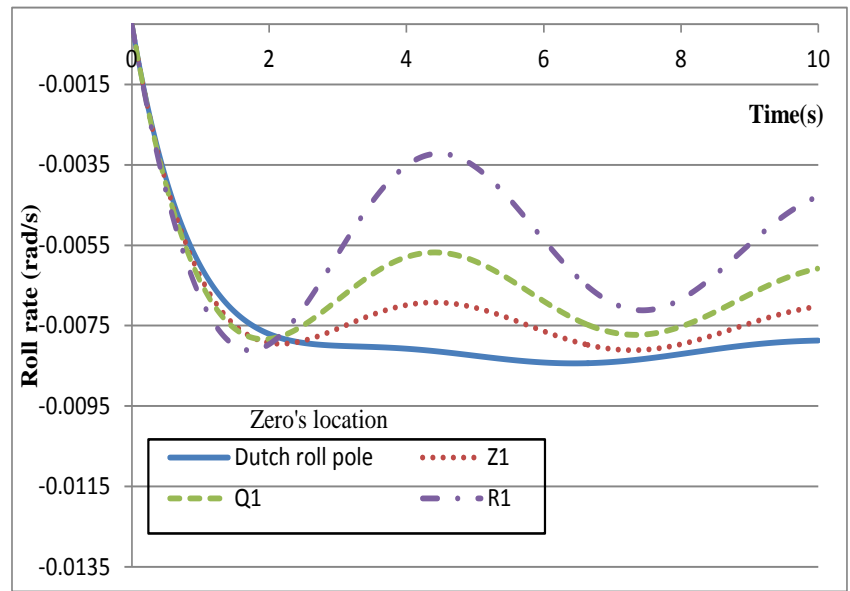

Fig.4-1 Roll rate response due to ailerons step input (1/2)

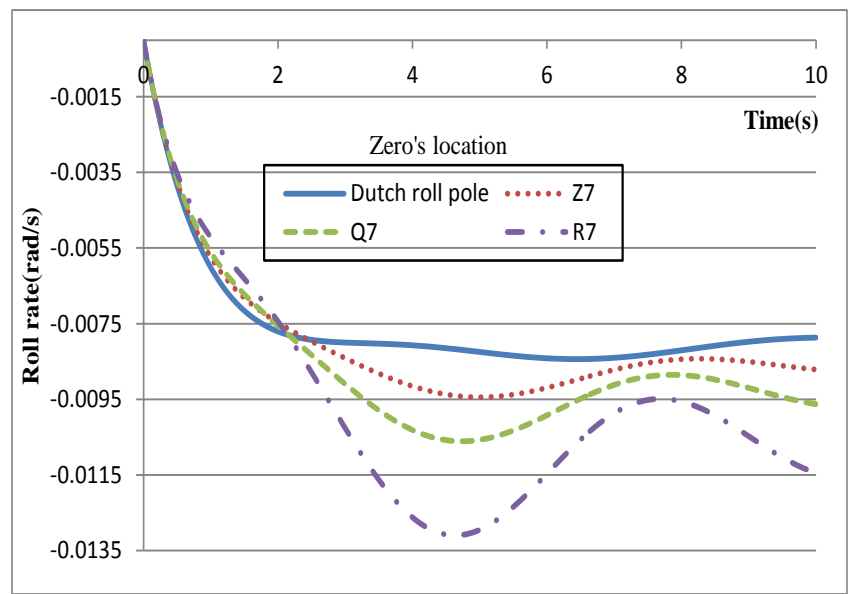

Fig.4-2 Roll rate response due to ailerons step input (2/2)

\section{5. 結論}

シミュレータ実験では、極の位置よりゼロ点の位置が離 れれば離れるほど操縦性が悪くなり、右上のほうに行くに つれて操縦性が悪くなった。解析の結果でも極からゼロ点 が離れれば離れるほど振動の大きさが大きくなり、右上に 行くほど最大ロールレート応答までの時間がかかった。ま た、ゼロ点が極に近いほど操縦性はよくなり左下は比較的 操縦性がよくなっていた。これは、4.の(2)で述べたように、 ロールレートの波形に差異が生じるからである。

以上のことから、運動解析して応答の波形を比較検討す ることで P.I.O.に入り易いかどうかを推測することができ る。

これらのことを踏まえて航空機を設計する際は、P.I.O. に入らないように、ゼロ点を極に対して近づけ、左下に配 置し、右上には配置しないようにすることが必要である。

参考文献

1.加藤寛一郎、他 : 航空機力学入門、東京大学出版会、1982 2. R.P.Harper Jr. \& G.E.Cooper : Handling Qualities and Pilot Evaluation, J. Guidance Vol.9, No.9, (1986) 